\title{
Two years of nitrogen and sulfur fertilizations in a signal grass pasture under degradation: changes in the root system ${ }^{1}$
}

\section{Cristiane Prezotto Silveira ${ }^{2}$, Daniela Alves de Oliveira $^{3}$, Edna Maria Bonfim-Silva ${ }^{4}$, Francisco Antonio Monteiro ${ }^{4}$}

1 Projeto apoiado pela FAPESP.

2 Universidade de São Paulo, Escola Superior de Agricultura “Luiz de Queiroz", Pós-graduação em Solos e Nutrição de Plantas. Bolsista da FAPESP

3 Universidade de São Paulo, Escola Superior de Agricultura "Luiz de Queiroz", Pós-graduação em Solos e Nutrição de Plantas. Bolsista da CAPES.

${ }^{4}$ Universidade de São Paulo, Escola Superior de Agricultura "Luiz de Queiroz", Departamento de Ciência do Solo, Piracicaba-SP-Brasil. Bolsista do CNPq.

ABSTRACT - The objective of this research was to evaluate the effect of combinations of nitrogen and sulfur rates in degraded signal grass (Brachiaria decumbens) pasture on their productive, morphological and nutritional attributes in the root system at four soil depths. The pasture used in the experiment was established over eight years ago in Entisol. Five nitrogen rates $(0 ; 150 ; 300 ; 450$ and $600 \mathrm{~kg} / \mathrm{ha} /$ year $)$ and five sulfur rates $(0 ; 15 ; 30 ; 45$ and $60 \mathrm{~kg} / \mathrm{ha} /$ year $)$ were combined in a fractionated factorial in a randomized block design, with three replications. Nitrogen was supplied as ammonium nitrate and sulfur as gypsum, and the rates were split into three times in the rainy season. The evaluations occurred at intervals of 35 days during the rainy season and 56 days in the dry season, in two consecutive years. Roots were collected with a 4-cm diameter auger at $0-10 ; 10-20 ; 20-30$ and 30-40 cm soil depths. It was determined root dry matter, length and surface of the root system and nitrogen and sulfur concentrations in roots. Nitrogen rates applied in two consecutive years in the pasture affected dry mass, length, surface and nitrogen concentration in signal grass root system. Rates of sulfur by themselves or combined with nitrogen rates do not affect attributes of root system.

Key Words: Brachiaria decumbens, dry mass, length, nitrogen concentration, surface

\section{Adubações com nitrogênio e enxofre durante dois anos em pastagem de capim-braquiária em degradação: alterações no sistema radicular}

RESUMO - Objetivou-se avaliar os efeitos das combinações de doses de nitrogênio e de enxofre em pastagem de capimbraquiária (Brachiaria decumbens) em degradação nos atributos produtivos, morfológicos e nutricionais do sistema radicular em quatro profundidades do solo. A pastagem utilizada no experimento foi estabelecida há mais de oito anos em solo Neossolo Quartzarênico. Cinco doses de nitrogênio $(0 ; 150 ; 300 ; 450$ e $600 \mathrm{~kg} / \mathrm{ha} / \mathrm{ano})$ e cinco doses de enxofre $(0 ; 15 ; 30 ; 45$ e $60 \mathrm{~kg} / \mathrm{ha} / \mathrm{ano}$ ) foram combinadas em fatorial fracionado, em delineamento de blocos ao acaso, com três repetições. O nitrogênio foi fornecido por meio de aplicação de nitrato de amônio e o enxofre por gesso, em doses parceladas em três vezes no período chuvoso. As avaliações ocorreram em intervalos de 35 dias no período chuvoso e de 56 dias no período seco, em dois anos consecutivos. As raízes foram coletadas por meio de trado de $4 \mathrm{~cm}$ de diâmetro nas profundidades de 0-10; 10-20; 20-30 e 30-40 cm do solo. Foram determinados a massa seca de raízes, o comprimento e a superfície radicular e as concentrações de nitrogênio e enxofre nas raízes. As doses de nitrogênio aplicadas em dois anos consecutivos na pastagem promoveram alterações nas raízes, em termos de massa seca, comprimento, superfície e concentração de nitrogênio no capim-braquiária. As doses de enxofre, isoladamente ou combinadas com as de nitrogênio, não promovem alterações nos atributos do sistema radicular.

Palavras-chave: Brachiaria decumbens, comprimento, concentração de nitrogênio, massa seca, superfície

\section{Introduction}

Millions of hectares of Brazilian pastures are degraded or under degradation. Brachiaria decumbens (signal grass) is the main species under degradation and fertilization has been fundamental for the recovery of the pastures with this grass. Despite the importance of roots in the pasture production and persistence, the available literature information about the biomass and morphology of root system is scarce (Cecato et al., 2004). According to 
Scurlock \& Hall (1998), less than $10 \%$ of the experiments with pastures evaluated the grass root system. In the experiments in which roots were usually evaluated, only the roots dry mass is measured, because it is more easily obtained than other attributes of the root system, such as length, surface, diameter and distribution in soil depth (Voorhees et al., 1980).

Most of the root mass of grasses (approximately 80\%) is concentrated in the upper $15 \mathrm{~cm}$ soil depth (Barker et al., 1988; Brazil et al., 2000). Rodrigues \& Cadima-Zevallos (1991), Bono et al. (2000) and Rodrigues et al. (2001) reported that the soil depth of 0 to $20 \mathrm{~cm}$ would be responsible for the greatest proportion of root volume. However, according to Anghinoni \& Meurer (1999), the root system of grasses is concentrated in the surface soil depth, mainly in the 0-5 cm layer.

By sampling roots of tanzania grass (Panicum maximum) in 0-40 cm soil depth, Santos Junior (2005) found that $65 \%$ of the root mass was in the 0 to $10 \mathrm{~cm}$ soil depth, $21 \%$ in the 10 to $20 \mathrm{~cm}, 9 \%$ in the 20 to $30 \mathrm{~cm}$ and $5 \%$ in the 30 to $40 \mathrm{~cm}$. Sarmento et al. (2008) collected $60 \%$ of the total root mass of IPR-86 milênio grass (Panicum maximum) in the 0 to $10 \mathrm{~cm}$ and $25 \%$ in the 10 to $20 \mathrm{~cm}$ soil depth.

The acquisition of nutrients by plants occurs through the root system. Thus, the amount of nutrients absorbed is determined by the total roots mainly present at the low soil depth (Anghinoni \& Meurer, 1999). The objective of this research was to study the effects of nitrogen and sulfur rates applications in a pasture of signal grass under degradation, in terms of morphological properties, dry mass and nutritional characteristics of the grass roots.

\section{Material and Methods}

The experiment was carried out in a commercial farm located in Piracicaba, São Paulo State, Brazil (47 57' 56" W and $22^{\circ} 46^{\prime} 30^{\prime \prime} \mathrm{S}$, with average altitude of $600 \mathrm{~m}$ ) from October 2005 to October 2007. The pasture contained signal grass (Brachiaria decumbens) which was established eight years before the experiment, in a soil classified as Entisol (EMBRAPA, 2006).

The root system of signal grass was collected in preestablished intervals of 35 days during the rainy season and 56 days in the dry season. In the first rainy season, the sampling dates were December, $21^{\text {st }} 2005$; January $25^{\text {th }}$ 2006; March $1^{\text {st }}$ 2006; April $5^{\text {th }} 2006$ and May $10^{\text {th }} 2006$, and in the first dry period samplings were done at July $5^{\text {th }}$ 2006; August $30^{\text {th }} 2006$ and October $25^{\text {th }}$ 2006. In the second rainy season roots were sampled at November $29^{\text {th }}$
2006; January $3^{\text {rd }}$ 2007; February $7^{\text {th }} 2007$; March $14^{\text {th }}$ 2007 and April 18 ${ }^{\text {th }}$ 2007, whereas in the second dry period the samplings were carried out on June $13^{\text {th }}$ 2007; August $8^{\text {th }} 2007$ and November $6^{\text {th }} 2007$.

Five nitrogen rates $(0,150,300,450$ and $600 \mathrm{~kg} / \mathrm{ha} /$ year $)$ and five sulfur rates $(0,15,30,45$ and $60 \mathrm{~kg} / \mathrm{ha}$ /year $)$ were combined in a surface response study in a fractionated $5^{2}$ factorial according to Littell \& Mott (1975), in randomized block design, with three replications. The 13 combinations of nitrogen and sulfur rates (kg/ha/year) were: 0-0, 0-30,0-60, 150-15, 150-45, 300-0, 300-30, 300-60, 450-15, 450-45, 600-0; $600-30$ and 600-60. The total area of the experiment was $1800 \mathrm{~m}^{2}$, with $5 \mathrm{~m} \times 8 \mathrm{~m}$ experimental plots.

Soil fertility characteristics in the $0-20 \mathrm{~cm}$ depth before the experiment were: $\mathrm{pH}\left(\mathrm{CaCl}_{2}\right)=4.1, \mathrm{OM}=9.1 \mathrm{~g} / \mathrm{dm}^{3}$, $\mathrm{P}=5.3 \mathrm{mg} / \mathrm{dm}^{3}, \mathrm{~K}=1.8 \mathrm{mmol}_{\mathrm{C}} / \mathrm{dm}^{3} ; \mathrm{Ca}=4.0 \mathrm{mmol}_{\mathrm{c}} / \mathrm{dm}^{3}$; $\mathrm{Mg}=2.3 \mathrm{mmol}_{\mathrm{c}} / \mathrm{dm}^{3} ; \mathrm{Al}=4.0 \mathrm{mmol}_{\mathrm{c}} / \mathrm{dm}^{3}, \mathrm{H}+\mathrm{Al}=$ $21.5 \mathrm{mmol}_{\mathrm{c}} / \mathrm{dm}^{3}$; total $\mathrm{N}=0.3 \mathrm{~g} / \mathrm{kg} ; \mathrm{SO}_{4}-\mathrm{S}=8.4 \mathrm{mg} / \mathrm{dm}^{3}$; $\mathrm{SB}=8.1 \mathrm{mmol}_{\mathrm{c}} / \mathrm{dm}^{3} ; \mathrm{CEC}=29.5 \mathrm{mmol}_{\mathrm{c}} / \mathrm{dm}^{3}$ and percentage base saturation $=26.8 \%$. Two months before the first evaluation in the experimental area, in order to increase the percentage of base saturation to $40 \%$ (according to Werner et al., 1996), it was demanded a dolomite limestone application of $600 \mathrm{~kg} / \mathrm{ha}$, which was manually distributed on the surface in order to maintain the integrity of the forage root system.

Fertilizations with nitrogen and sulfur were applied three times during the rainy season (November $17^{\text {th }} 2005$; December $23^{\text {rd }} 2005$ and January $28^{\text {th }} 2006$ ) and $1 / 3$ of that fertilization was applied one month after liming, $1 / 3$ after the first plant evaluation and $1 / 3$ after the second plant evaluation. In the second year, lime was not applied, but nitrogen and sulfur fertilizations were also split in three applications during the rainy season (October $28^{\text {th }} 2006$, December $2^{\text {nd }} 2006$ and August $1^{\text {st }}$ 2007). Nitrogen was supplied as $\mathrm{NH}_{4} \mathrm{NO}_{3}$ and sulfur as $\mathrm{CaSO}_{4} \cdot 2 \mathrm{H}_{2} \mathrm{O}$. Phosphorus was supplied as triple superfosfate $\left(\mathrm{P}_{2} \mathrm{O}_{5}=\right.$ $30 \mathrm{~kg} / \mathrm{ha} /$ year) and potassium as potassium chloride $\left(\mathrm{K}_{2} \mathrm{O}=30 \mathrm{~kg} / \mathrm{ha} /\right.$ year $)$. Micronutrient was supplied as FTE $\mathrm{Br}-16$ at $30 \mathrm{~kg} / \mathrm{ha} / \mathrm{year}$, as recommended by Monteiro et al. (2004). These fertilizations were performed at the time of the first nitrogen and sulfur applications, in each of the two years.

Root samples were collected by using an auger ( $4 \mathrm{~cm}$ in diameter), at $0-10,10-20,20-30$ and $30-40 \mathrm{~cm}$ of soil depths. Roots were separated from the soil through a $1.00 \mathrm{~mm}$ sieve, the roots were washed in water in a $0.25 \mathrm{~mm}$ sieve and placed in plastic cups containing deionized water. Subsequently, roots were scanned and their images submitted to evaluation of root system surface 
and length by using the SIARCS (Integrated System for Root and Soil Cover Analysis) version 3.0 (Crestana et al., 1994). After being scanned, the root samples from each soil depth were dried in a forced-air ventilated oven at $65^{\circ} \mathrm{C}$ until constant mass, with subsequent weighing and grinding.

The concentrations of nitrogen and sulfur in the roots at $0-40 \mathrm{~cm}$ soil depth (the roots collected from each soil depth were put together for chemical analysis) were determined by using a method described by Sarruge \& Haag (1974). Nitrogen was determined by the micro Kjeldahl method and sulfur was determined by the turbidimetric method.

Statistical analysis was done by using Statistical Analysis System (SAS, 1999), at 5\% significance level. The analysis of variance ( $F$ test) was initially performed and, for the significant interaction between nitrogen and sulfur rates, a polynomial regression (response surface analysis) was calculated by using the RSREG procedure, and $\mathrm{R}^{2}$ was recalculated. For data with no significance for this interaction, the General Linear Model (GLM) procedure was used for the first and second degree regression analysis.

\section{Results and Discussion}

The interaction nitrogen rates $\times$ sulfur rates was not significant for root dry mass of signal grass in two years of evaluations. Moreover, nitrogen rates were significant for the roots dry mass. In the rainy and dry seasons of the first year of evaluations, nitrogen rates significantly affected roots dry mass and the results fit to the linear regression model, varying the roots dry mass from 1.2 to $1.8 \mathrm{~g} / \mathrm{dm}^{3}$ at $30-40 \mathrm{~cm}$ soil depth (Figure $1 \mathrm{a}$ ) in the first rainy season and from 11.2 to $14.2 \mathrm{~g} / \mathrm{dm}^{3}$ at $0-10 \mathrm{~cm}$ soil depth (Figure 1b) in the first dry season.

In the second rainy season, nitrogen rates significantly affected root dry mass at 20-30 and 30-40 cm soil depths and the results fit to the quadratic model and linear
$30-40 \mathrm{~cm}: \mathrm{Y}=1.1968+0.0008 \mathrm{~N}\left(\mathrm{R}^{2}=0.62\right)$

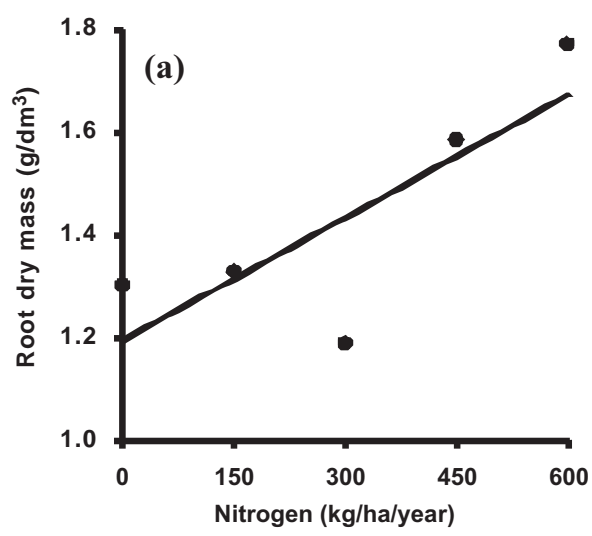

- 20-30 cm: $Y=1.748-0.0021 \mathrm{~N}+0.000005 \mathrm{~N}^{2}\left(\mathrm{R}^{2}=0.99\right)$ - 30-40 cm: $Y=1.0296+0.0009 N\left(R^{2}=0.88\right)$

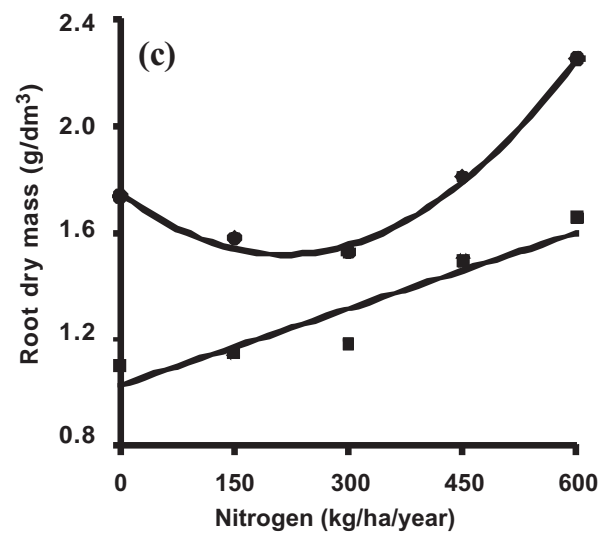

$0-10 \mathrm{~cm}: \mathrm{Y}=11.6459+0.0038 \mathrm{~N}\left(R^{2}=0.73\right)$

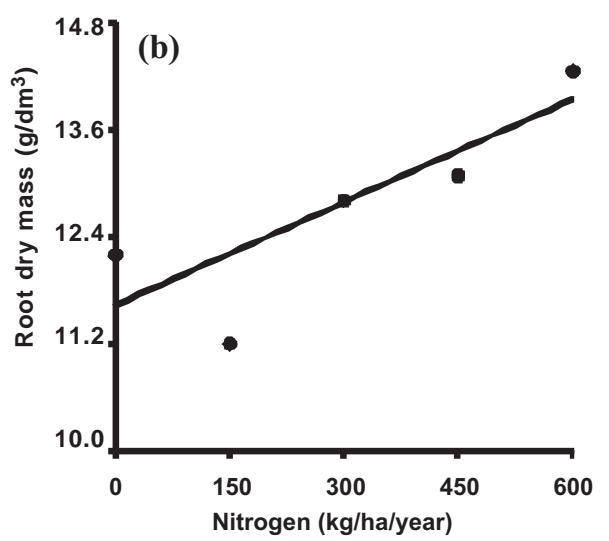

- $10-20 \mathrm{~cm}: \mathrm{Y}=4.2927-0.0031 \mathrm{~N}+0.000007 \mathrm{~N}^{2}\left(\mathrm{R}^{2}=0.86\right)$ 30-40 cm: $Y=2.2018-0.0042 \mathrm{~N}+0.000008 \mathrm{~N}^{2}\left(\mathrm{R}^{2}=0.79\right)$

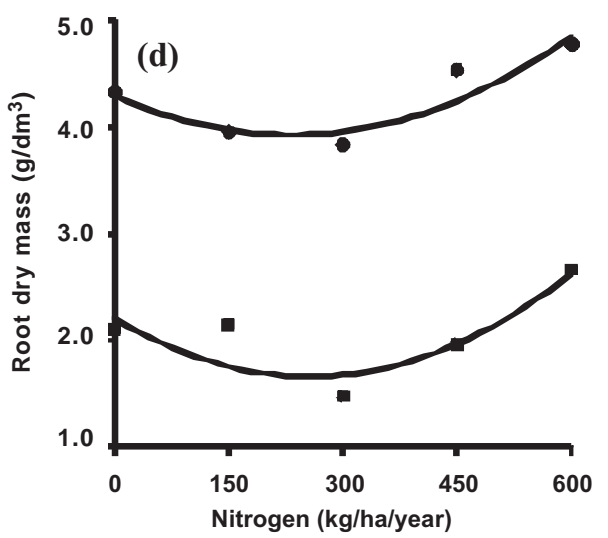

Figure 1 - Root dry mass of signal grass in the first rainy (a) and dry (b) seasons, and in second rainy (c) and dry (d) seasons, as related to nitrogen rates. 
regression, respectively. Root dry mass varied from 1.5 to 2.2 and from 1.1 to $1.7 \mathrm{~g} / \mathrm{dm}^{3}$ at these soil depths, respectively (Figure 1c). Nitrogen rates significantly affected root dry mass at 10-20 and 30-40 cm soil depths in the second dry season and the results fit to the quadratic regression model. For the $10-20 \mathrm{~cm}$ soil depth, root dry mass varied from 4.8 to 3.8 and from 1.5 to $2.7 \mathrm{~g} / \mathrm{dm}^{3}$ for $30-40 \mathrm{~cm}$ soil depth (Figure 1d).

Nitrogen rates were significant for the total root dry mass in the first experimental year (rainy + dry seasons) at $30-40 \mathrm{~cm}$ soil depth and the values from 2.3 to $3.0 \mathrm{~g} / \mathrm{dm}^{3} \mathrm{fit}$ to the quadratic regression model (Figure 2a). In the second year (rainy + dry seasons), nitrogen rates were significant for the total roots dry mass at soil depths of $10-20,20-30$ and $30-40 \mathrm{~cm}$. These results in the second year fit to the quadratic regression model, with values ranging from 6.6 to 8.0 , from 4.1 to 6.0 and from 2.7 to $4.3 \mathrm{~g} / \mathrm{dm}^{3}$, respectively, at those soil depths (Figure $2 \mathrm{~b}$ ).

Root dry mass of signal grass showed significant effects of nitrogen rates as a consequence of the nitrogen potential to significantly change the growth and morphology of the roots (Marschner, 1995). For this same grass, Bonfim-Silva \& Monteiro (2010) reported significant effects of nitrogen rates in the dry mass of roots.

About $65 \%$ of the total of signal grass roots system in the soil depth of $0-40 \mathrm{~cm}$ was at $0-10 \mathrm{~cm}$ soil depth, $18 \%$ at $10-20 \mathrm{~cm}, 10 \%$ in the $20-30 \mathrm{~cm}$ and $7 \%$ at $30-40 \mathrm{~cm}$. Therefore, $83 \%$ of root dry mass was found at the $0-20 \mathrm{~cm}$ soil depth. Similar results were found by Santos Junior (2005) for the root system of tanzania grass (Panicum maximum) and by Sarmento et al. (2008) with IPR-86 milênio

$30-40 \mathrm{~cm}: \mathrm{Y}=2.7149-0.0026 \mathrm{~N}+0.000005 \mathrm{~N}^{2}\left(\mathrm{R}^{2}=0.77\right)$

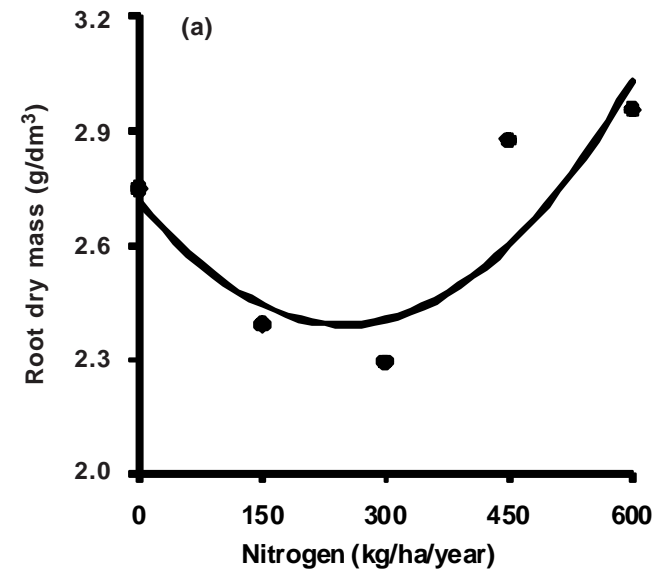

grass (Panicum maximum). Rodrigues \& Cadima-Zevallos (1991), Bono et al. (2000) and Rodrigues et al. (2001) also reported that the $0-20 \mathrm{~cm}$ soil depth contained much of the root dry mass of forage grasses.

The interaction nitrogen rates $\times$ sulfur rates was not significant for the root length in any evaluation of the grass in the two years. On the other hand, nitrogen rates were significant for root length sampled in the first rainy season. The root length varied from 78 to $94 \mathrm{~m} / \mathrm{dm}^{3}$ at 0-10 cm soil depth and from 13 to $19 \mathrm{~m} / \mathrm{dm}^{3}$ at $30-40 \mathrm{~cm}$ soil depth, and the results fit to quadratic and linear regressions at 0-10 and 30-40 cm soil depth, respectively (Figure 3a).

In the first dry season, only nitrogen rates resulted in significant changes in root length at $0-10 \mathrm{~cm}$ soil depth and the results (from 91 to $112 \mathrm{~m} / \mathrm{dm}^{3}$ ) fit to the quadratic regression model (Figure $3 b$ ). In the second rainy season, the nitrogen rates significantly changed root length at 10-20, 20-30 and 30-40 cm soil depths, and the results fit to the quadratic model for soil depths of $10-20$ and $20-30 \mathrm{~cm}$, and fit to the linear regression for $30-40 \mathrm{~cm}$ soil depth. The root length varied from 38 to 47, from 25 to 31 and from 19 to $26 \mathrm{~m} / \mathrm{dm}^{3}$ at $10-20,20-30$ and $30-40$ soil depths, respectively (Figure 3c).

Nitrogen rates significantly affected the root length at $0-10,10-20$ and $30-40 \mathrm{~cm}$ soil depth in the second dry season. The results fit to the quadratic regression models, and varied from 121 to 150 , from 50 to 66 and from 28 to $37 \mathrm{~m} / \mathrm{dm}^{3}$ for the $0-10,10-20$ and $30-40 \mathrm{~cm}$ soil depths, respectively (Figure 3d).

Nitrogen rates were significant for root length at 0-10 and $10-20 \mathrm{~cm}$ soil depth as a total measured in the first year
10-20 cm: $Y=7.4117-0.0047 \mathrm{~N}+0.00001 \mathrm{~N}^{2}\left(\mathrm{R}^{2}=0.75\right)$

- 20-30 cm: $Y=4.5569-0.0031 N+0.000009 N^{2}\left(R^{2}=0.82\right)$

30-40 cm: $Y=3.3028-0.0043 N+0.00001 N^{2}\left(R^{2}=0.87\right)$

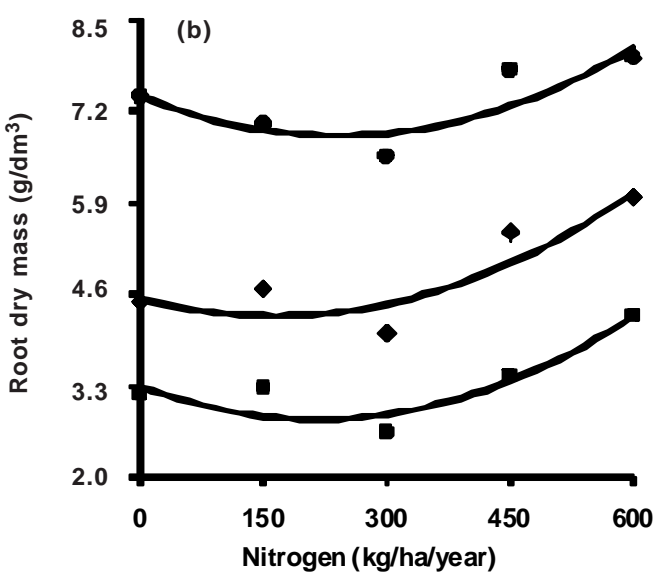

Figure 2 - Root dry mass of signal grass in response to nitrogen rates at the first (a) and second (b) years of evaluation. 
(rainy + dry seasons). The results fit to the quadratic regression model and changed from 169 to 206 and from 69 to $85 \mathrm{~m} / \mathrm{dm}^{3}$ at $0-10$ and $10-20 \mathrm{~cm}$ soil depths, respectively (Figure 4a). The total root length in the second year (rainy + dry seasons) was significantly influenced by nitrogen rates at 10-20, 20-30 and 30-40 cm soil depths. The results varied from 89 to 113 , from 62 to 77 and from 48 to $63 \mathrm{~m} / \mathrm{dm}^{3}$, respectively, at those soil depths (Figure 4b), and fit to the quadratic regression model.

Signal grass root length was significantly changed by nitrogen rates. Plants well supplied with nitrogen present roots more developed than those deficient in this nutrient, because the mechanisms involved in root growth are related to the accumulation of carbohydrates (Brouwer, 1962).
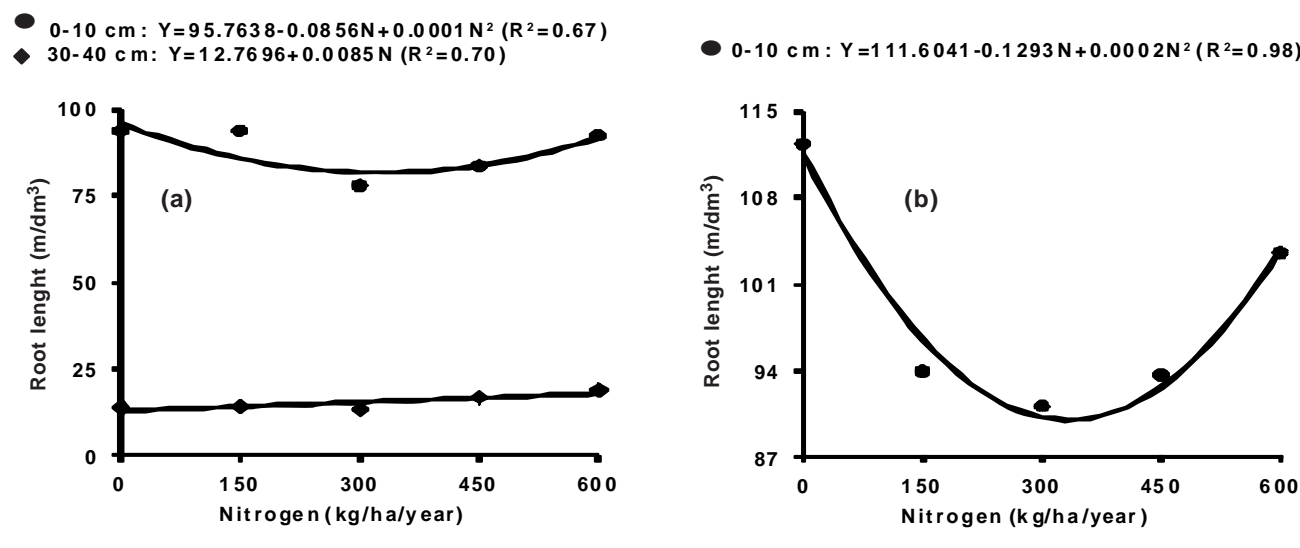

$10-20 \mathrm{~cm}: Y=47.1061-0.0464 \mathrm{~N}+0.00007 \mathrm{~N}^{2}\left(R^{2}=0.92\right)$
$20-30 \mathrm{~cm}: Y=27.9193-0.0189 \mathrm{~N}+0.00004 \mathrm{~N}^{2}\left(\mathrm{R}^{2}=0.97\right)$ $20-30 \mathrm{~cm}: Y=27.9193-0.0189 \mathrm{~N}+0.00004 \mathrm{~N}^{2}$
$30-40 \mathrm{~cm}: \mathrm{Y}=18.4889+0.0104 \mathrm{~N}\left(\mathrm{R}^{2}=0.80\right)$

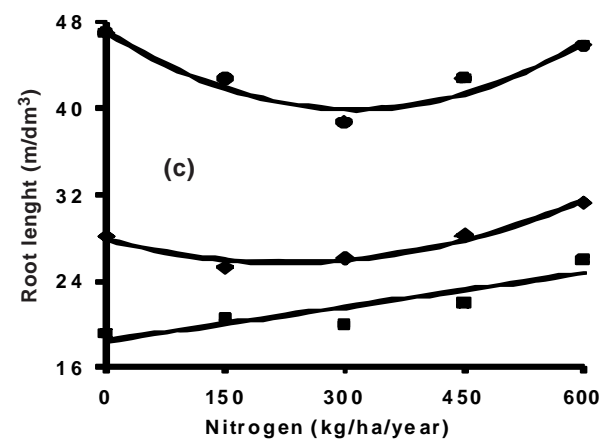

$0-10 \mathrm{~cm}: Y=147.3819-0.1429 \mathrm{~N}+0.0002 \mathrm{~N}^{2}\left(R^{2}=0.81\right)$
$10-20 \mathrm{~cm}: Y=64.9628-0.0877 \mathrm{~N}+0.0001 \mathrm{~N}^{2}\left(R^{2}=0.92\right)$

$10-20 \mathrm{~cm}: Y=64.9628-0.0877 \mathrm{~N}+0.0001 \mathrm{~N}^{2}\left(R^{2}=0.92\right)$
$30-40 \mathrm{~cm}: \mathrm{Y}=38.7148-0.0571 \mathrm{~N}+0.00009 \mathrm{~N}^{2}\left(R^{2}=0.69\right)$

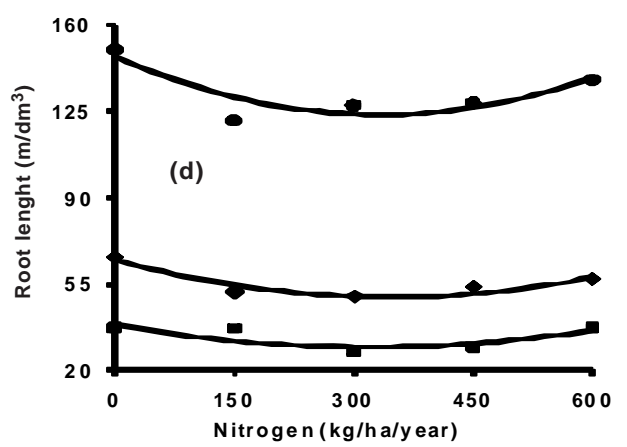

Figure 3 - Root length of signal grass in the first rainy (a) and dry (b) seasons, and in the second rainy (c) and dry (d) seasons, as related to nitrogen rates.

$0-10 \mathrm{~cm}: Y=207.3703-0.2149 \mathrm{~N}+0.0003 \mathrm{~N}^{2}\left(R^{2}=0.96\right)$
$10-20 \mathrm{~cm}: Y=84.2361-0.0787 \mathrm{~N}+0.0001 \mathrm{~N}^{2}\left(R^{2}=0.70\right)$

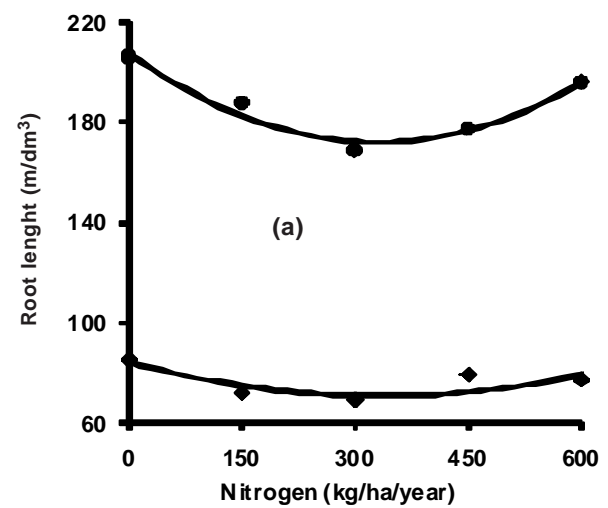

10-20 cm: $Y=112.0683-0.1342 \mathrm{~N}+0.0002 \mathrm{~N}^{2}\left(R^{2}=0.95\right)$

20-30 cm: $Y=73.6011-0.057 \mathrm{~N}+0.0001 \mathrm{~N}^{2}\left(\mathrm{R}^{2}=0.65\right)$

- 30-40 cm: $Y=58.2567-0.0618 \mathrm{~N}+0.0001 \mathrm{~N}^{2}\left(R^{2}=0.73\right)$

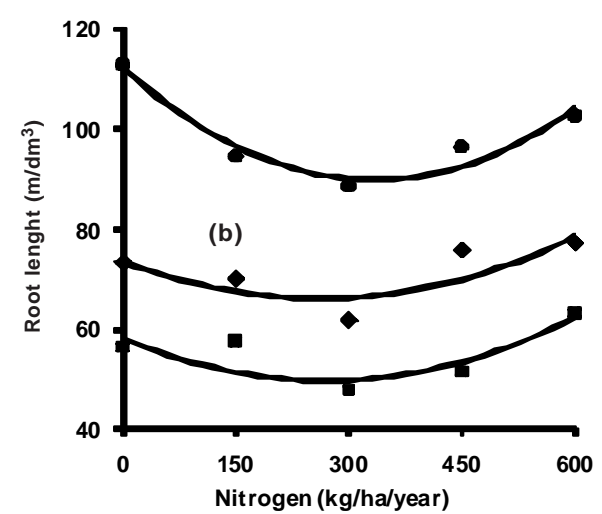

Figure 4 - Root length of signal grass in response to nitrogen rates as a total of the first (a) and second (b) years of evaluation. 
By studying nitrogen rates associated with sulfur rates for signal grass recovery, Bonfim-Silva \& Monteiro (2010) showed that nitrogen rates affected the root length and the production of roots dry mass and surface. Batista (2006) also found that nitrogen rates affected the root length of Marandu palisade grass (Brachiaria brizantha).

The interaction nitrogen $\times$ sulfur rates was not significant for the root surface of the signal grass in any evaluation in the two years. However, in the first rainy season there was significant effect of nitrogen rates for the root surface and the results (from 99 to $162 \mathrm{~cm}^{2} / \mathrm{dm}^{3}$ ) fit to the linear regression model at the $30-40 \mathrm{~cm}$ soil depth (Figure 5a). In the first dry season, nitrogen rates significantly influenced the root surface only at the $0-10 \mathrm{~cm}$ soil depth, with results varying from 875 to $1051 \mathrm{~cm}^{2} / \mathrm{dm}^{3}$ and fit to the quadratic regression model and (Figure 5b).

In the second rainy season, nitrogen rates significantly affected the roots surface at $20-30$ and $30-40 \mathrm{~cm}$ soil depths
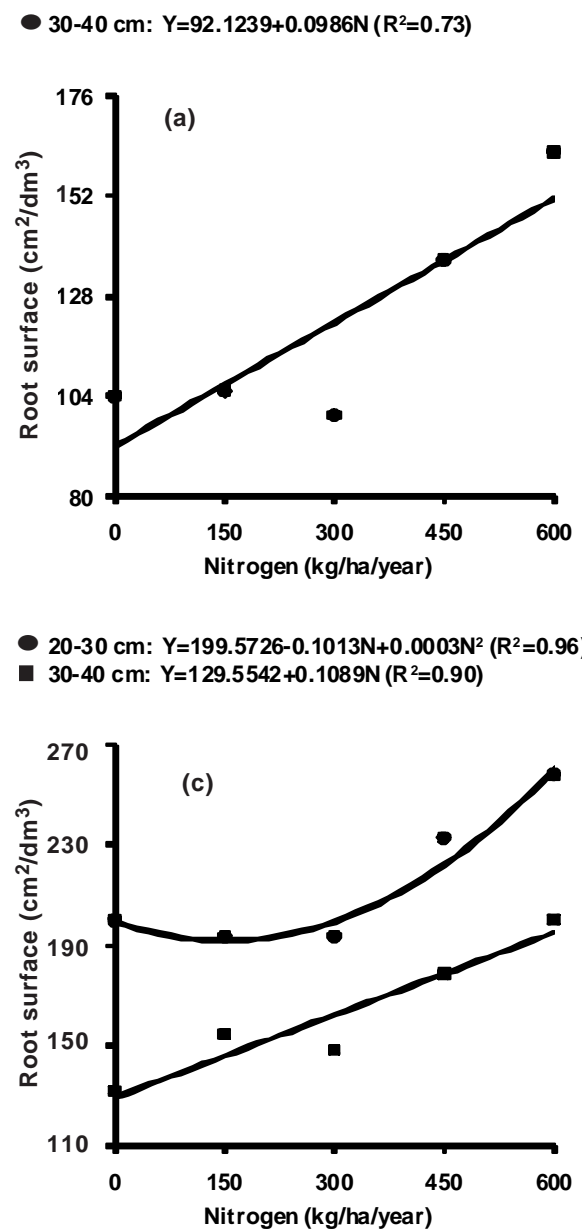

and the results fit to the quadratic and linear regression models, respectively. The root surface, measured at 20-30 cm soil depth, varied from 193 to $258 \mathrm{~cm}^{2} / \mathrm{dm}^{3}$ and from 132 to $200 \mathrm{~cm}^{2} / \mathrm{dm}^{3}$ at $30-40 \mathrm{~cm}$ soil depth (Figure $5 \mathrm{c}$ ). Significant changes in the root surface at soil depths 10-20 and $30-40 \mathrm{~cm}$ in the second dry season were observed as a result of nitrogen supply and the results fit to the quadratic regression model. For the $10-20$ and $30-40 \mathrm{~cm}$ soil depths, the roots surface varied from 420 to 499 and from 214 to $316 \mathrm{~cm}^{2} / \mathrm{dm}^{3}$, respectively (Figure $5 \mathrm{~d}$ ).

Nitrogen rates were significant for the roots surface at $0-10 \mathrm{~cm}$ soil depth as a total in the first experimental year (rainy + dry seasons) and the results fit the quadratic regression model, with values ranging from 1,674 to $2,036 \mathrm{~cm}^{2} / \mathrm{dm}^{3}$ (Figure 6a). In the second year (rainy + dry seasons), nitrogen rates were significant for the root surface at $10-20$ and $30-40 \mathrm{~cm}$ soil depths, with the results ranging from 733 to 861 and from 362 to $517 \mathrm{~cm}^{2} / \mathrm{dm}^{3}$, respectively, and fit to the quadratic regression model (Figure 6b).

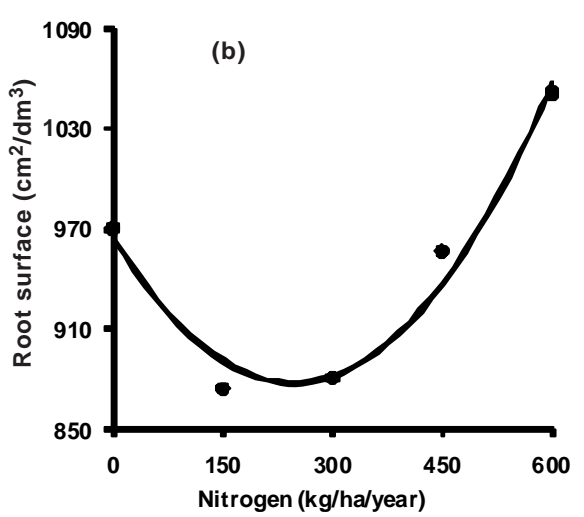

$10-20 \mathrm{~cm}: Y=64.9628-0.0877 \mathrm{~N}+0.0001 \mathrm{~N}^{2}\left(R^{2}=0.92\right)$ - 30-40 cm: $Y=38.7148-0.0571 \mathrm{~N}+0.00009 \mathrm{~N}^{2}\left(R^{2}=0.69\right.$ '

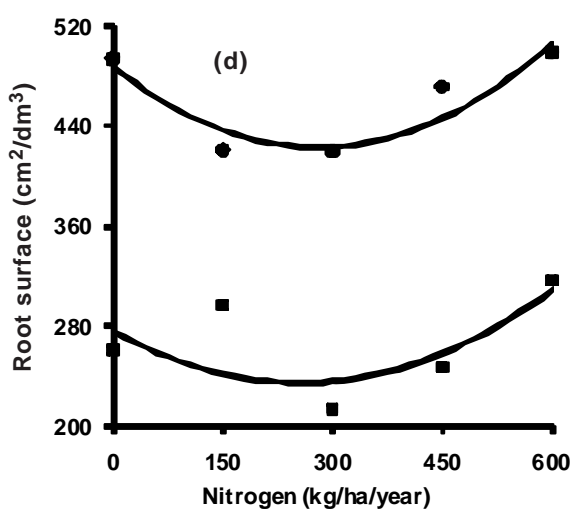

Figure 5 - Root surface of signal grass of the first rainy (a) and dry (b) seasons, and in the second rainy (c) and dry (d) seasons, as related to nitrogen rates. 
The results for root surface and length of signal grass showed similar effects as both were significantly influenced by nitrogen rates. Batista \& Monteiro (2006), Monteiro \& Consolmagno Neto (2008) and Megda \& Monteiro (2010) found that root length and surface were adequate attributes for the development of root system evaluation.

Nitrogen concentration in signal grass roots collected at $0-40 \mathrm{~cm}$ soil depth showed no significance for the interaction nitrogen $\times$ sulfur rates in the two years.

0-10 cm: $Y=1849.0523-1.1134 \mathrm{~N}+0.0024 \mathrm{~N}^{2}\left(R^{2}=0.88\right)$

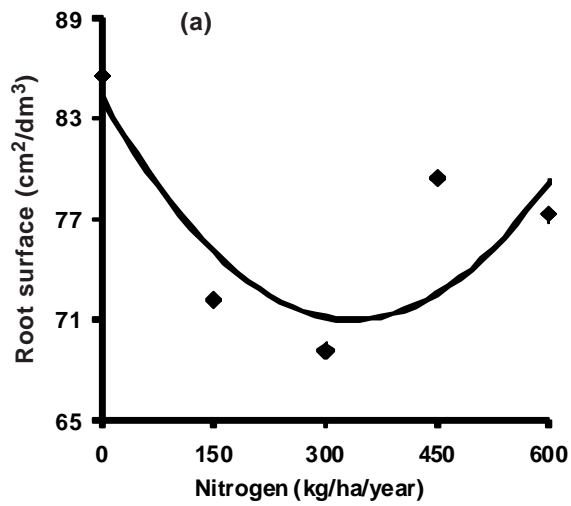

However, nitrogen rates were significant for the nitrogen concentrations in the roots in each of the seasons (Figure 7). The results fit to the linear regression model for the first rainy and dry seasons (Figures $7 \mathrm{a}$ and $7 \mathrm{~b}$ ) and fit to the quadratic regression model for the second rainy and dry seasons. The maximum nitrogen concentration in roots in the rainy and dry seasons was found when the nitrogen rate was $357 \mathrm{~kg} / \mathrm{ha} /$ year (Figure 7c) and $540 \mathrm{~kg} / \mathrm{ha} /$ year (Figure 7d), respectively.
10-20 cm: $Y=830.2726-0.5602 \mathrm{~N}+0.001 \mathrm{~N}^{2}\left(R^{2}=0.82\right)$

$30-40 \mathrm{~cm}: \mathrm{Y}=410.7967-0.2906 \mathrm{~N}+0.0007 \mathrm{~N}^{2}\left(R^{2}=0.69\right)$

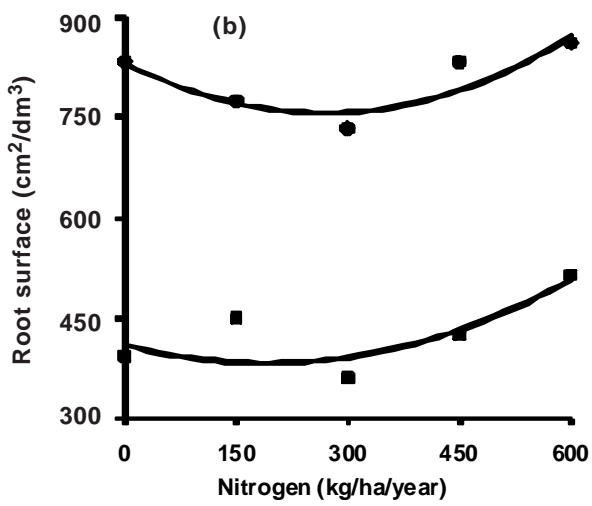

Figure 6 - Root surface of signal grass in response to nitrogen rates in the first (a) and second (b) years of evaluation.
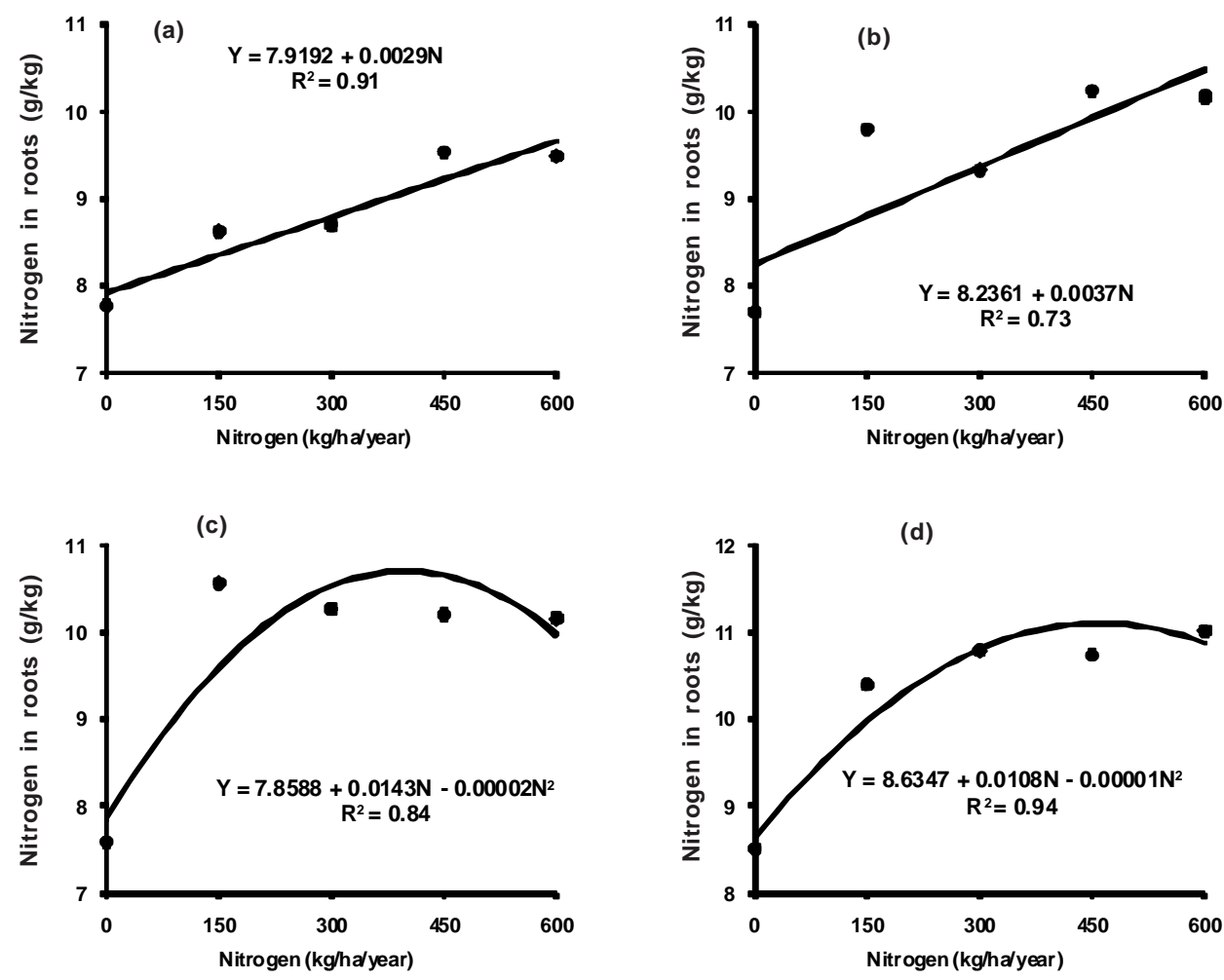

Figure 7 - Nitrogen concentration in roots of signal grass collected at 0-40 cm soil depth in the first rainy (a) and dry (b) seasons, and in the second rainy (c) and dry (d) seasons, as related to nitrogen rates. 
Nitrogen concentration in roots taken at $0-40 \mathrm{~cm}$ soil depth varied from 7.8 to $9.5 \mathrm{~g} / \mathrm{kg}$ in the first rainy season, from 7.7 to $10.2 \mathrm{~g} / \mathrm{kg}$ in the first dry season, from 7.6 to $10.6 \mathrm{~g} / \mathrm{kg}$ in the second rainy season and from 8.5 to $11.0 \mathrm{~g} / \mathrm{kg}$ in the second dry season (Figure 7).

As an average of each first and second year of experiment, nitrogen rates significantly changed nitrogen concentrations in the roots collected at $0-40 \mathrm{~cm}$ soil depth, with the results fitting to the linear and quadratic regression models, respectively. In the first year, nitrogen concentrations in roots varied from 7.7 to $9.9 \mathrm{~g} / \mathrm{kg}$ (Figure 8a). In the second year, nitrogen concentrations in roots varied from 8.1 to $10.4 \mathrm{~g} / \mathrm{kg}$ and the maximum nitrogen concentration in roots was found with the nitrogen rate of $483 \mathrm{~kg} / \mathrm{ha} /$ year (Figure 8b).

(a)

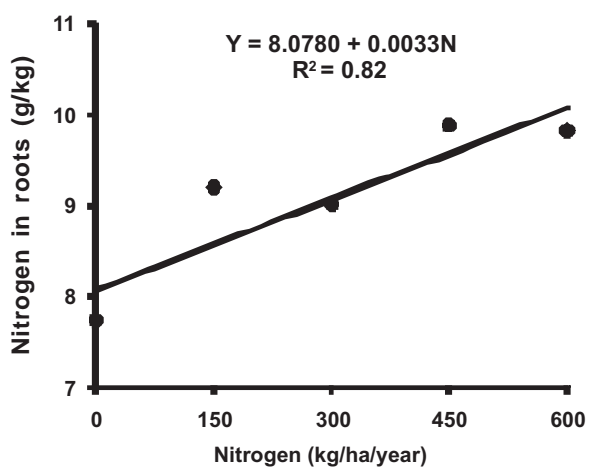

Nitrogen concentration in the roots of signal grass was significantly affected by nitrogen fertilizations (Figures 7 and 8). Bonfim-Silva \& Monteiro (2010) reported that the nitrogen rates increased nitrogen concentrations in roots of signal grass. Kanno et al. (2001) also reported a similar effect for the roots of tanzania grass. Batista (2006) found significant changes in nitrogen concentrations in the roots as a result of nitrogen supply at fixed sulfur rates.

Sulfur concentrations in roots collected at $0-40 \mathrm{~cm}$ soil depth showed no significance for the interaction nitrogen $\times$ sulfur rates. Effects were also not found for nitrogen rates or sulfur rates in the concentration of this nutrient in roots of signal grass, during the two years. (b)

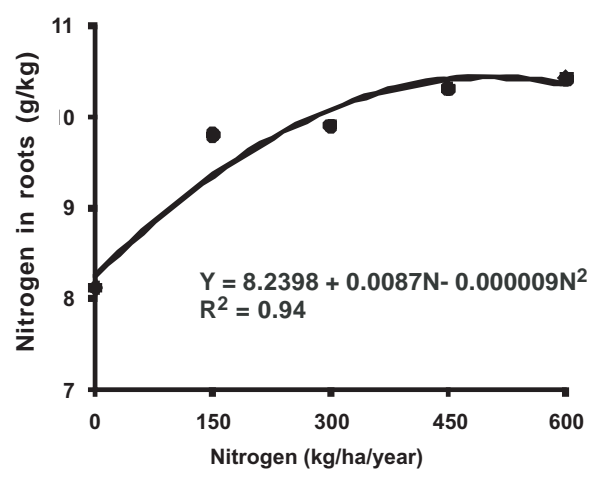

Figure 8 - Nitrogen concentration in signal grass roots collected at 0-40 cm soil depth in the first (a) and second (b) years of evaluation, as related to nitrogen rates.

\section{Conclusions}

The supply of nitrogen in two consecutive years results in significant changes in signal grass roots as expressed by dry mass, length, surface and nitrogen concentration. Sulfur neither provides significant effects nor interacts with nitrogen for these root of signal grass.

\section{References}

ANGHINONI, I.; MEURER, E.J. Eficiência de absorção de nutrientes pelas raízes. In: WORKSHOP SOBRE SISTEMA RADICULAR: metodologias e estudo de casos, 1999, Aracaju. Anais... Aracaju: EMBRAPA Tabuleiros Costeiros, 1999. p.57-87.

BARKER, D.J.; ZHANG, D.M.; MACKAY, A.D. Root distribution in a low fertility hill country sward grazed by sheep. New
Zealand Journal of Experimental Agriculture, v.16, n.1, p.73-76, 1988.

BATISTA, K. Nitrogênio e enxofre na implantação do capimMarandu em substituição ao capim-braquiária em degradação num solo com baixa matéria orgânica. 2006 125f. Tese (Doutorado em Solos e Nutrição de Plantas) - Escola Superior de Agricultura “Luiz de Queiroz”/Universidade de São Paulo, Piracicaba.

BATISTA, K.; MONTEIRO, F.A. Sistema radicular do capimMarandu, considerando as combinações de doses de nitrogênio e de enxofre. Revista Brasileira de Ciência do Solo, v.30, n.1, p.821-828, 2006.

BONFIM-SILVA, E.M.; MONTEIRO, F.A. Nitrogênio e enxofre na adubação e em folhas diagnósticas e raízes do capimbraquiária em degradação. Revista Brasileira de Zootecnia, v.39, n.8, p.1641-1649, 2010.

BONO, J.A.; MACEDO, M.C.M.; EUCLIDES, V.B.P. Biomassa e área do sistema radicular e resistência do solo a penetração em pastagens de Panicum maximum Jacq. sob pastejo rotacionado. In: REUNIÃO ANUAL DA SOCIEDADE BRASILEIRA DE 
ZOOTECNIA, 37., 2000, Viçosa, MG. Anais... Viçosa, MG: Sociedade Brasileira de Zootecnia, [2000]. (CD-ROM).

BRASIL, F.C.; STOCCO, F.C.; PESSANHA, A.L. et al. Distribuição e variação temporal de características radiculares de Brachiaria humidicola em um Planossolo. In: REUNIÃO ANUAL DA SOCIEDADE BRASILEIRA DE ZOOTECNIA, 37., 2000, Viçosa, MG. Anais... Viçosa, MG: Sociedade Brasileira de Zootecnia, [2000]. (CD-ROM).

BROUWER, R. Nutritive influences on the distributions of dry matter in the plant. Netherlands Journal of Agricultural Science, v.10, n.5, p.399-408, 1962.

CECATO, U.; JOBIM, C.C.; REGO, F.C.A. et al. Sistema radicular - componente esquecido das pastagens. In: SIMPÓSIO SOBRE MANEJO ESTRATÉGICO DA PASTAGEM, 2., 2004, Viçosa, MG. Anais... Viçosa, MG: UFV, 2004. p.159-207.

CRESTANA, S.; GUIMARÃES, M.F.; JORGE, L.A.C. et al. Avaliação da distribuição de raízes no solo auxiliada por processamento de imagens digitais. Revista Brasileira de Ciência do Solo, v.18, n.3, p.365-371, 1994.

EMPRESA BRASILEIRA DE PESQUISA AGROPECUÁRIA CNPS. Sistema brasileiro de classificação de solos. 2.ed. Rio de Janeiro: Embrapa Solos, 2006. 306p.

KANNO, T.; MACEDO, M.C.M.; UOZUMI, S. et al. Development of grassland management technology for sustainable agropastoril systems in the Sub-Tropical zone in Brazil. JIRCAS Working Report, v.19, n.1, p.63-73, 2001.

LITTELL, R.C.; MOTT, G.O. Computer assisted design and analysis of response surface experiments in agronomy. Soil and Crop Society of Florida Proceedings, v.34, n.5, p.94-97, 1975.

MARSCHNER, H. Mineral nutrition of higher plants. 2.ed. London: Academic Press, 1995. 889p.

MEGDA, M.M.; MONTEIRO, F.A. Nitrogen and potassium supply and the morphogenic and productive characteristics of marandu palisadegrass. Revista Brasileira de Zootecnia, v.39, n.8, p.1666-1675, 2010

MONTEIRO, F.A.; COLOZZA, M.T.; WERNER, J.C. Enxofre e micronutrientes em pastagens. In: SIMPÓSIO SOBRE MANEJO
DA PASTAGEM, 21., 2004, Piracicaba. Anais... Piracicaba: FEALQ, 2004. p.279-301.

MONTEIRO, F.A.; CONSOLMAGNO NETO; D. Sistema radicular do capim-tanzânia adubado com potássio e magnésio. Revista Brasileira de Zootecnia, v.37, n.5, p.810-818, 2008.

RODRIGUES, A.C.G.; CADIMA-ZEVALLOS, A. Efeito da intensidade de pastejo sobre o sistema radicular de pastagem. Pesquisa Agropecuária Brasileira, v.26, n.3, p.439-445, 1991.

RODRIGUES, L.R.; RODRIGUES, T.J.D.; RAMOS, A.K.B. et al. Dry matter production of shoots and root density of two cultivars of Lablab purpureus (L.) Sweet. In: INTERNATIONAL GRASSLAND CONGRESS, 19., 2001, Águas de São Pedro. Proceedings... Piracicaba: FEALQ, 2001. p.573-574.

SANTOS JUNIOR, J.D.G. Fertilidade do solo no acúmulo de forragem e nutrição do capim-Tanzânia sob pastejo na região dos Cerrados. 2005. 105f. Tese (Doutorado em Solos e Nutrição de Plantas) - Escola Superior de Agricultura "Luiz de Queiroz"/Universidade de São Paulo, Piracicaba.

SARMENTO, P.; RODRIGUES, L.R.A; LUGÃO, S.M.B. et al. Sistema radicular do Panicum maximum Jacq. cv. IPR-86 Milênio adubado com nitrogênio e submetido à lotação rotacionada. Revista Brasileira de Zootecnia, v.37, n.1, p.27-34, 2008.

SARRUGE, J.R.; HAAG, H.P. Análises químicas em plantas. Piracicaba: ESALQ, 1974. 54p.

SCURLOCK, J.M.O.; HALL, D.O. The global carbon sink: a grassland perspective. Global Change Biology, v.4, n.2, p.229-233, 1998.

STATISTICAL ANALYSIS SYSTEM - SAS. User's guide statistics: version 8.0 edition. Cary, 1999. 956p.

VOORHEES, W.B.; CARLSON, V.A.; HALLAUER, E.A. Root length measurement with a computer-controlled digital scanning microdensitometer. Agronomy Journal, v.72, n.2, p.847-850, 1980.

WERNER, J.C.; PAULINO, V.T.; CANTARELLA, H. et al. Forrageiras. In: RAIJ, B. van; CANTARELLA, H.; QUAGGIO, J.A.; FURLANI, A.M.C. (Eds.). Recomendações de adubação e calagem para o Estado de São Paulo. Campinas: Instituto Agronômico e Fundação IAC, 1996. p.261-273. 